\title{
Endemic plants from the Southern Brazilian Highland Grasslands
}

\author{
Josimar Külkamp ${ }^{1,3}$, Gustavo Heiden ${ }^{2}$ \& João Ricardo Vieira Iganci ${ }^{1}$
}

\begin{abstract}
The flora of the subtropical highland grasslands in Southern Brazil, locally known as Campos de Cima da Serra, is within the Atlantic Forest hotspot, and has being highlighted by its richness, having around $25 \%$ of endemic plants. Those formations require specific studies to estimate its species richness and to protect its natural resources. This study aimed to map and to analyze the distribution of endemic taxa from these grasslands based on available herbarium collections databases as sources for highlighting important taxonomic groups for future studies. We verified how much of those endemic taxa are inside protected areas, and recognized the most important taxa and areas for future studies. All the data about each endemic taxon was obtained through visiting herbaria, online databases, collecting expeditions and published references. Distribution maps for endemic species were prepared. As the main result, we describe and map the distribution of the endemic flora of this species rich vegetation formation and highlight the threatened taxa as priority for future taxonomic and conservation studies. Our results also point out the central-west of Santa Catarina and central Paraná states as priority areas for future studies considering its high diversity of taxa.
\end{abstract}

Key words: Atlantic Forest hotspot, distribution, herbarium, subtropical vegetation, taxonomy.

\section{Resumo}

A vegetação subtropical dos campos de altitude do sul do Brasil, localmente conhecida por Campos de Cima da Serra, está dentro do hotspot do bioma Mata Atlântica. Possui destaque devido à sua elevada riqueza de espécies, apresentando aproximadamente $25 \%$ de plantas endêmicas. Esta formação requer mais estudos específicos para estimar sua riqueza de espécies e proteger os recursos naturais. Este estudo teve como objetivo mapear e analisar a distribuição de táxons endêmicos nos campos de altitude baseando-se em dados de coleções de herbários como fonte para destacar importantes grupos taxonômicos para futuros estudos. Verificou-se quantos desses táxons endêmicos encontram-se dentro de áreas de proteção e os táxons e áreas mais importantes para futuros estudos foram reconhecidos. Todos os dados sobre cada táxon endêmico foram obtidos através de visitas a herbários, bancos de dados online, expedições de coleta e referências bibliográficas. Foram preparados mapas de distribuição para os táxons endêmicos. Como principal resultado, a distribuição da flora endêmica dos campos de cima da serra foi descrita e mapeada. Os táxons destacados como ameaçados são prioritários para futuros estudos taxonômicos e conservacionistas. Nossos resultados apontam o centro-oeste de Santa Catarina e o centro do estado do Paraná como áreas prioritárias para futuros estudos, considerando sua alta diversidade de táxons.

Palavras-chave: hotspot da Mata Atlântica, distribuição, herbário, vegetação subtropical, taxonomia.

\section{Introduction}

During the Convention on Biological Diversity (COP 8, Curitiba 2006), as the first goal on the Global Strategy for Plant Conservation (GSPC), it was established to provide a functional list of known species in 2010, being a first step to build a global plant species list. This collaborative work was produced by an international team and compiled in the Brazilian Flora Checklist (BFG 2015). The next step is to prepare complete monographs including descriptions, identification keys and distribution information for all plant

See supplementary material at $<$ https://figshare.com/s/71d93f859b513760c760>

\footnotetext{
${ }^{1}$ Universidade Federal do Rio Grande do Sul, Prog. Pós-graduação em Botânica, Av. Bento Gonçalves 9500, B1. IV, Prédio 43433, 91501-970, Porto Alegre, RS, Brazil.

${ }^{2}$ Embrapa Clima Temperado, Rod. BR-392, km 78, C.P. 403, 96010-971, Pelotas, RS, Brazil.

${ }^{3}$ Author for correspondence: josimarbotanica@gmail.com
} 
species integrating the Brazilian Flora 2020 project (Brazilian Flora 2020 in construction 2016).

Understanding the distribution patterns of diversity within an area of interest for conservation is essential prior to the implementation of effective strategies (Sankaran 2009). A recent study by Rösch et al. (2015) brought to light the duality between establishing few large protected areas versus many small protected areas. The authors argue that a much higher proportion of species-area accumulation is found in many small protected areas, and that besides large protected areas, it is also necessary to establish a new diversified fragmented habitat strategy covering a greater geographic extent. Different assembles of species are found along vegetation gradients of a single ecosystem, requiring much more protected areas to encompass a highest biodiversity (Vieira et al. 2015). Thus, effective conservation studies claim for the identification and mapping of specific communities at local, regional and continental scales (Dixon et al. 2014).

Brazil harbors a worldwide recognized great species diversity along different ecosystems, and its species diversity is directly linked to the different habitats available (BFG 2015). Besides the great progress on forest ecosystems conservation during the past decades, non-forest ecosystems have been neglected in conservation policies in Brazil (Overbeck et al. 2007; Overbeck et al. 2015). Recognizing, characterizing and mapping neglected ecosystem is a primordial tool for highlighting its importance and claim for conservation efforts (Dixon et al. 2014; Särkinen et al. 2011). Grasslands and other open vegetation ecosystem are still misrepresented and neglected in conservation policies (Veldeman et al. 2015).

The vegetation in Southern Brazil is composed of different ecosystems, characterizing a transitional area between tropical and temperate landscapes (Rambo 1953; Safford 2007; Smith 1962). Thus, the habitat heterogeneity allows the existence of a high diversity of exclusive plants (Iganci et al. 2011). Those species are restricted to isolate patches next to ecologically and floristically distinct formations. The high diversity of endemic taxa in Southern Brazil has a complex history with million years of local adaptations (Iganci et al. 2013).

The Subtropical Highland Grasslands cover the Serra Geral mountain range, which is a set of mountains located in the Paraná Basin found further south of Brazil (Scheibe 1986) (Fig. 1). They are within the Atlantic Forest hotspot, and harbor a great diversity of endemic plant species (Iganci et al. 2011). Those grasslands are also neglected in research priorities and conservation policies (Overbeck et al. 2007; Iganci et al. 2011). This vegetation formation is locally known in Southern Brazil as Campos de Cima da Serra (CCS). This local name was firstly used by Fortes (1959), referring to the Northeastern Rio Grande do Sul

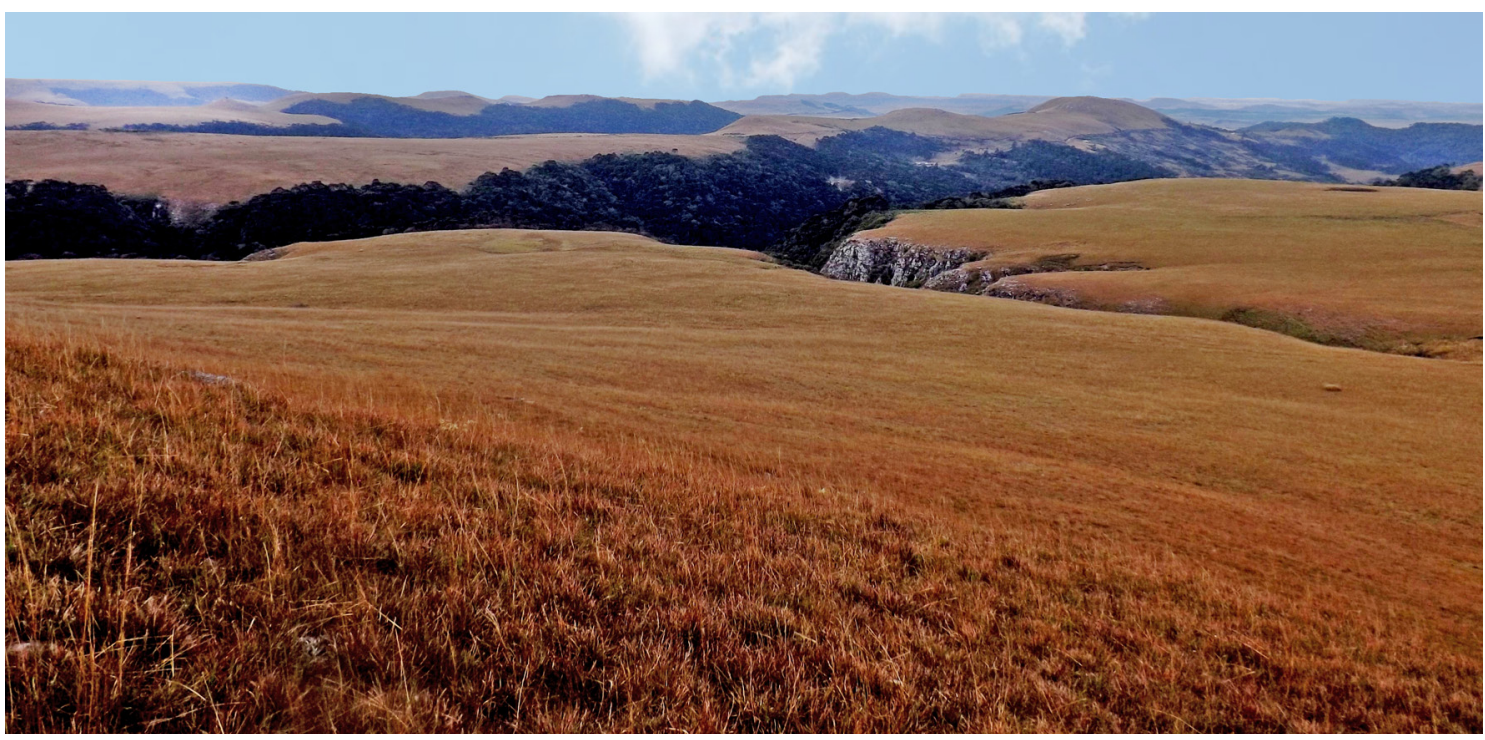

Figure 1 - Southern Brazilian Highland Grasslands during the Winter, at the São Joaquim National Park, Santa Catarina state. 
highland grasslands, and was expanded by Iganci et al. (2011) to the entire ecosystem, including the grasslands from the whole Serra Geral range. The CCS is the richest vegetation formation from Southern Brazil in endemic angiosperms, harboring around 25\% (296 taxa) of endemic plants (Fig. 2) (Iganci et al. 2011). This high diversity makes the CCS as a whole, a priority for conservation studies. Concerning the protect areas within the CCS (Tab. 1 in supplementary material $<$ https:// figshare.com/s/71d93f859b513760c760>), there are national parks, state parks, biological reserves, local permanent protection areas, national forests, ecological stations, relevant ecological interest areas, and wildlife refugees (Brasil 2014a). However, over the Serra Geral range, it is evident the fast loss of natural habitats, being replaced by large mechanized agricultural areas, forestry and orchards. Consequently, the land use over the CCS brings extinction risks for grasslands species (Boldrini et al. 2009; Lopes et al. 2010), being the protect areas of extreme importance for maintaining species diversity. Therefore, aiming a systematic planning for conservation, it is necessary to produce precise information about species distribution. Restrict narrow endemic species should receive higher attention and priority for conservation as banner species to protect entire communities (Giulietti et al. 2009; Wulff et al. 2013).

This study moves forward on the knowledge of the species rich Campos de Cima da Serra grasslands, aiming to estimate its current taxonomic knowledge and the distribution of its endemic flora. We map the endemic taxa of the CCS to recognize
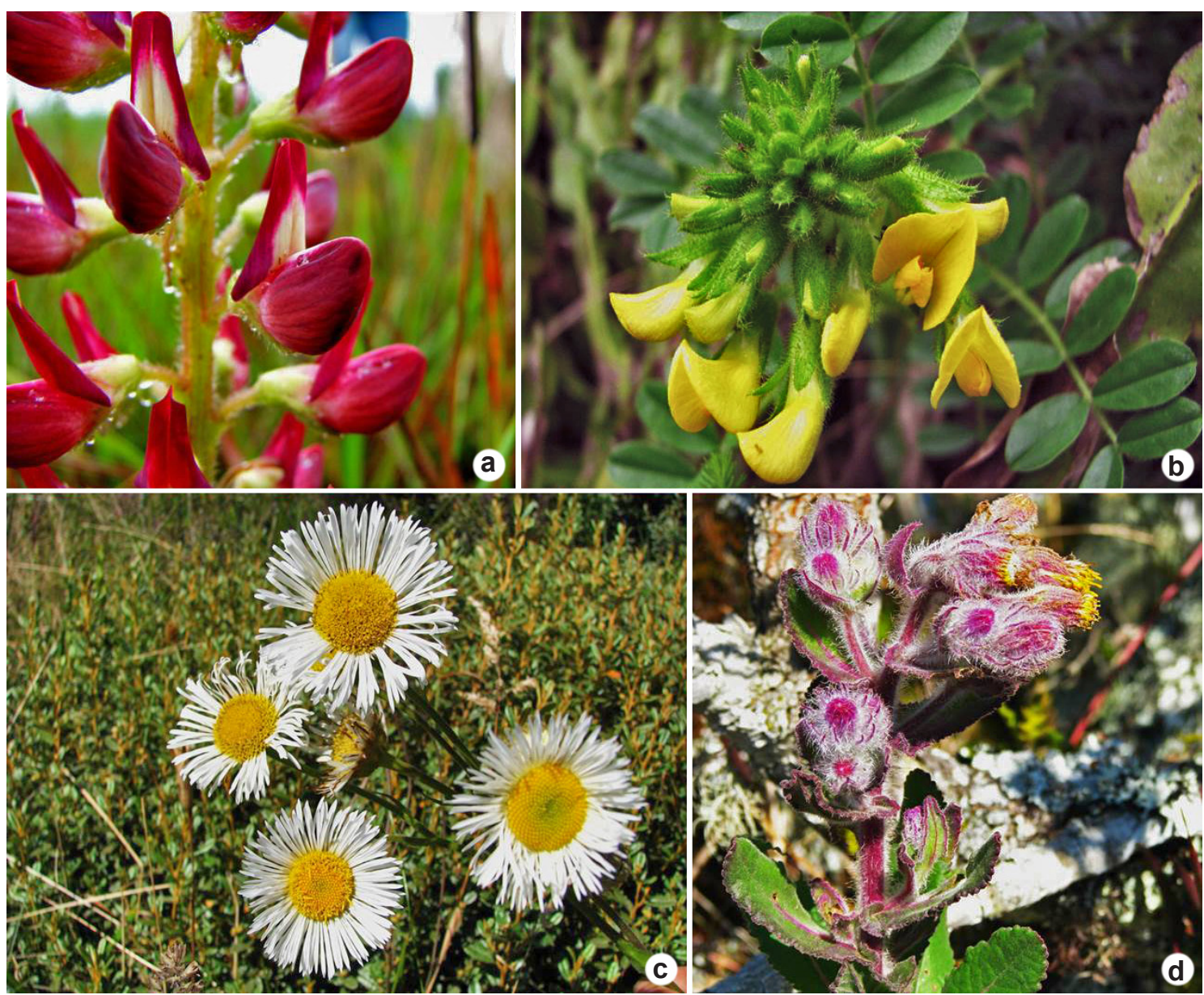

Figure 2 - Examples of endemic plants from the Southern Brazilian Highland Grasslands - a. Lupinus rubriflorus - Fabaceae; b. Adesmia reitziana - Fabaceae; c. Leptostelma catharinense - Asteraceae; d. Senecio conyzifolius Asteraceae. 
the richest areas, based on endemic plants, as priority areas for future taxonomic and conservation studies. We based the research on the following questions: 1) What is the current knowledge about endemic taxa based in herbarium collections? 2) Is it possible to recognize distribution patterns for the endemic species over the CCS? 3) Are the CCS endemic taxa within protected areas?

\section{Material and Methods}

\section{Study area}

The CCS comprises around 1,374,000 ha (Boldrini et al. 2009), and occurs over elevation areas, reaching up to $1,800 \mathrm{~m}$ in a subtropical or temperate climate. This grassland ecosystem is found south of the Tropic of Capricorn, between

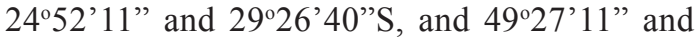
$53^{\circ} 43^{\prime} 51^{\prime \prime} \mathrm{W}$. These grasslands are montane or upper-montane ecosystems, where herbaceous and shrubby plants dominate the landscape, in a heterogeneous formation compound by patches of grasslands, swampy areas and rocky outcrops (Boldrini et al. 2009; Iganci et al. 2011). The Brazilian biomes classification includes the CCS within the Atlantic Forest biome (IBGE 2012) controversially clustering this grassland ecosystem within the Atlantic Forest which predominates in Eastern Brazil. The vegetation is remarkable by an abrupt change on the natural sequence of the surrounding plant species from the ombrophilous mixed forest (Araucaria forest) dominated by Araucaria angustifolia (Bertol.) Kuntze (Brasil 2008). The climate over the CCS is Cfb (following Köppen 1931), temperate humid (Peel et al. 2007), with rainfall distributed along the year and medium temperature between $12{ }^{\circ} \mathrm{C}$ (average minimum temperature in July, $10{ }^{\circ} \mathrm{C}$ ) and $18{ }^{\circ} \mathrm{C}$ (average medium temperature in January, $27^{\circ} \mathrm{C}$ ). Those current climatic conditions support the expansion of forests over the grasslands (Behling 2002; Almeida 2009). During the Pleistocene, from 42 to $10 \mathrm{Mya}$, the climate in this region was cooler and dryer, favoring the dominance of grasslands (Behling 2002). However, during the last $10 \mathrm{My}$, the temperature increased, turning the climate more humid and favoring the expansion of the Araucaria forest and the Atlantic rain forest over the grasslands (Behling 2002; Behling \& Pillar 2007; Duarte et al. 2006).

\section{Dataset and analyses}

We base the study on the list of 296 endemic taxa from the subtropical highland grasslands
(CCS) and rocky outcrops from Southern Brazil (Iganci et al. 2011). Geographic distribution data for each taxon was compiled from herbarium collections, bibliography, and field works, as well as online databases (speciesLink/CRIA and GBIF). In a first attempt to update the list of endemic taxa, we also consulted newer references related to species diversity on Southern Brazilian grasslands (including the Brazilian Flora 2020 in construction), and new taxa recently described to the ecosystem.

In order to increase the quality and reliability of the data, a thorough cleaning proceeded. When duplicate data were found it was excluded and left only one record for each collection. When data lacked geographic coordinates, they were also excluded from the list, leaving only the georeferenced and reliable records. Based on this database about species occurrences, we prepared distribution maps using DIVA-GIS 7.5.7. There were also estimated the species richness (number of different taxa in each grid), and collection richness (number of collections in each grid), searching for the most diverse areas in endemic plants, to direct future conservation studies. The results were plotted in maps using different color intensities according to the indices per grid of $625 \mathrm{~km}^{2}$ in the real plane $(25 \times 25 \mathrm{~km})$. The grids size was defined based on the large scale study area and on the resolution of resulting maps. After identifying the most important areas of distribution for endemic plants from the CCS, a shape layer containing the protected areas was plotted to verify how much of those taxa were recorded inside protected areas. Each record was double checked to highlight the taxa which presented records inside protected areas, and also the ones recorded from the border areas of protected areas. All taxa with conflicting or doubtful information were excluded from the dataset. Considering the distribution of records visualized on DIVA-GIS 7.5.7 it was possible to define which taxa are recorded inside the protected areas. There were also highlighted the taxa which occur only inside protected areas or endemic to exclusive specific areas. The list of endemic taxa from the CCS was compared with the regional red lists such as for the states of Rio Grande do Sul (Rio Grande do Sul 2015) and Santa Catarina (Reis \& Sedrez 2008), the List of Rare Plants from Brazil (Giulietti et al. 2009), the Red List of Brazilian Flora (Martinelli \& Moraes 2013), and the Red List of threatened species by the 
International Union for Conservation of Nature (IUCN 2015). The taxa which were not assessed on those red lists, were analyzed using the criteria established by the IUCN Red List Categories and Criteria Version 3.1 (IUCN 2001). The most influential treats were the loss of habitat, extent of occurrence (EOO) and area of occupancy of the taxa (AOO) (IUCN 2001; Martinelli \& Moraes 2013). The AOO and the EOO were calculated using GeoCAT-Kew (Bachman et al. 2011), based on geographic coordinates. The criteria established for each taxon are indicated after the categories of threat (Tab. 1 in supplementary material $<$ https:// figshare.com/s/71d93f859b513760c760>).

\section{Results}

From the 296 endemic taxa cited to the CCS (Iganci et al. 2011), 116 endemic taxa (ca. 40\%) were representative to sample and map based on the availability of 1,143 georeferenced records. Due to the complete lack of distribution georeferenced records for $45 \%$ of the total endemic flora, many taxa could not be included in the mapping analysis. Those 116 taxa mapped represent 30 different plant families (Tab. 1 in supplementary material $<$ https:// figshare.com/s/71d93f859b513760c760>).

The remaining fragments of grasslands with higher endemic species richness and collection richness in Southern Brazil are found in the
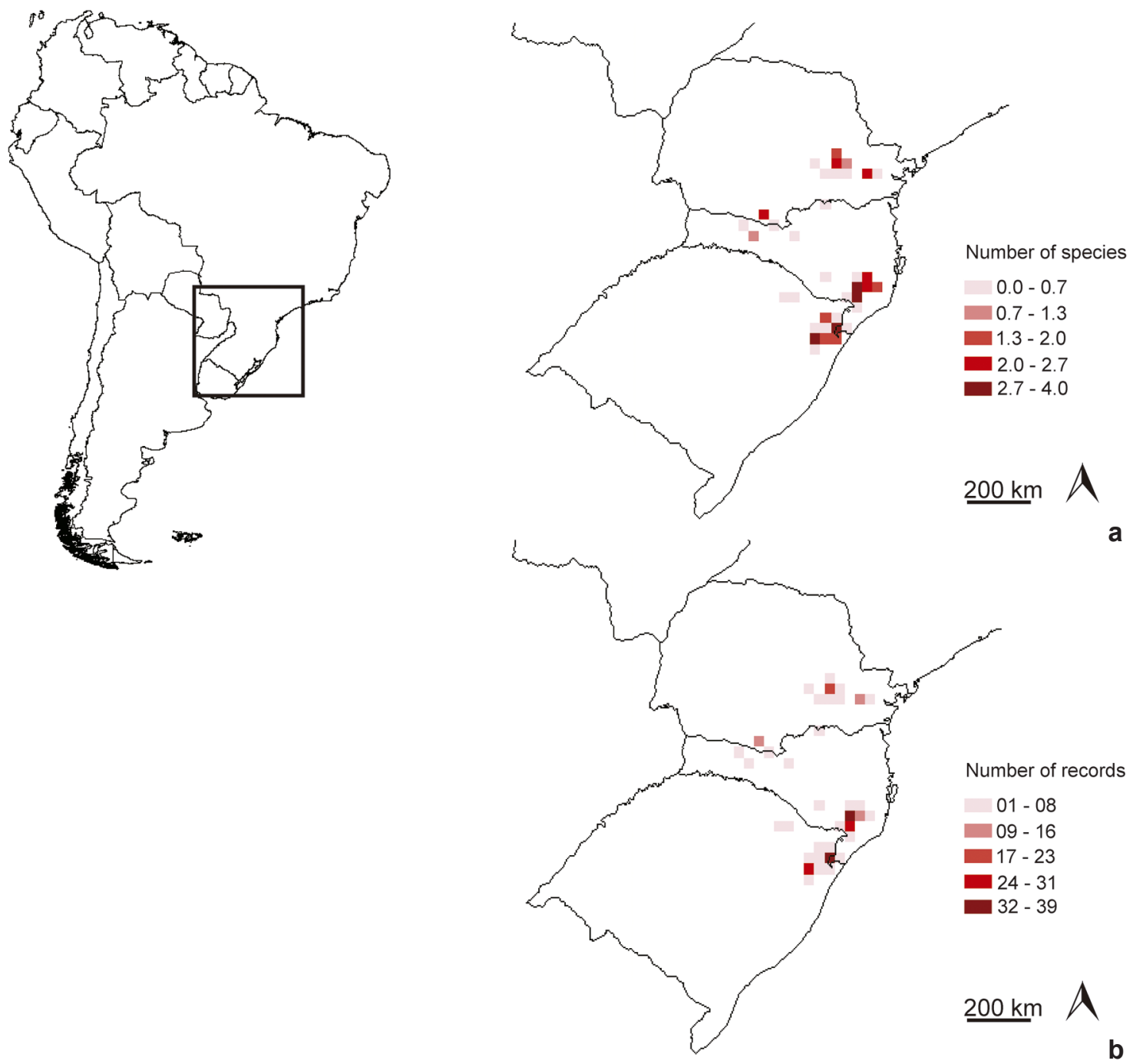

Figure 3 - Distribution of endemic taxa over the Southern Brazilian Highland Grasslands - a. number of species; b. number of records per quadrat. 
Northeast of Rio Grande do Sul state, over the highland areas in Central to West of Santa Catarina state, and most of the highland areas in Central and East of Paraná state (Fig. 3). Comparing those areas, it is possible to observe higher collection richness over the grasslands near the east edge of the plateau in Santa Catarina state (near São Joaquim National Park, Urubici). A higher species richness was observed near Curitiba, in the East of Paraná state, and in the Northeast of Rio Grande do Sul state. Those results could reflect both a higher species richness over the highlighted areas, or collecting efforts concentrated on some National Parks and easy access areas near large towns.

From the 116 endemic taxa sampled to the CCS, 41\% (48 taxa) were recorded inside protected areas, and 7\% (8 taxa) were recorded only inside protected areas. The majority (59\%) were recorded only outside protected areas (Fig. 4).
The protected area which presented more endemic taxa was the São Joaquim National Park, in Santa Catarina state (35 taxa). Other protected areas with records for endemic plant taxa were the Pró-Mata (6 taxa) and Aparados da Serra National Park (6 taxa), in Rio Grande do Sul state, and the Vila Velha State Park (3 taxa), and Palmas State Park (1 taxon), in Paraná state.

Sixty seven taxa representing $23 \%$ of the total number of endemic plants from the CCS are included in threatened species lists from Brazil (Tab. 1 in supplementary material $<$ https:// figshare.com/s/71d93f859b513760c760>; Tab. 2; Fig. 5). From the total 296 endemic taxa, $18.5 \%$ (55 taxa) are included in the Red List of Brazilian Flora (Martinelli \& Moraes 2013), 9\% (27 taxa) were included in the List of Threatened Species from Rio Grande do Sul state (Rio Grande do Sul 2015), 7.5\% (23 taxa) were listed in the Threatened

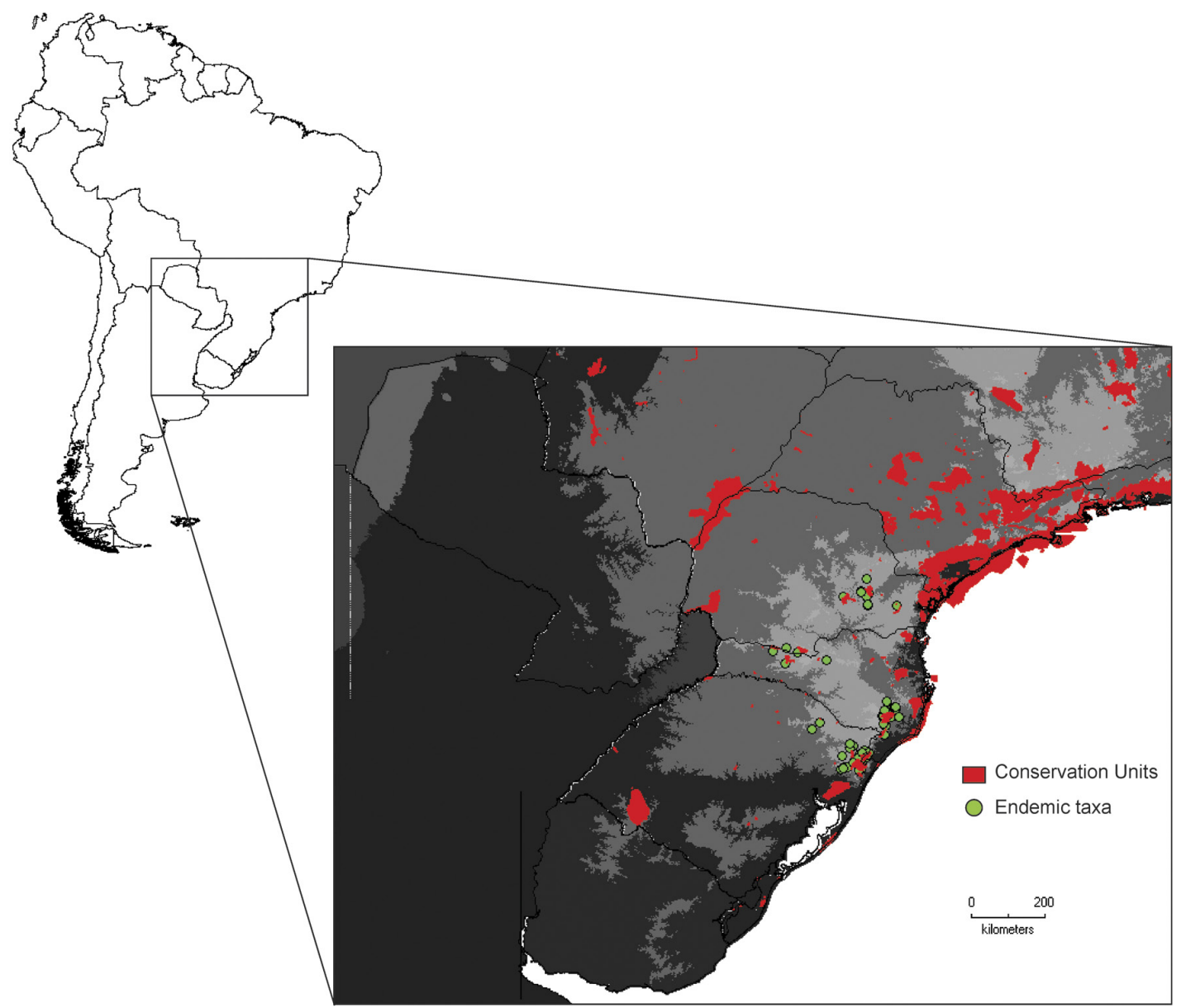

Figure 4 - Geographic distribution of endemic taxa from the Southern Brazilian Highland Grasslands and the occurrence within Protected areas (indicated in red). 
Table 2 - Summary of threatened taxa endemic to the Southern Brazilian Highland Grasslands. Conservation status: $\mathrm{CR}=$ Critically Endangered; EN = Endangered; VU = Vulnerable; NT = Near Threatened; LC = Least Concern; $\mathrm{DD}=$ Deficient Data. Red lists: $\mathrm{CNCFlora}=$ Red book of the Brazilian flora; MMA = Official list of the Brazilian threatened flora; Regional RS = Red list of the threatened flora in Rio Grande do Sul state; Regional SC $=$ Red list of the threatened flora in Santa Catarina state.

\begin{tabular}{lcccccc}
\hline \multirow{2}{*}{ Red lists } & \multicolumn{7}{c}{ Conservation status } \\
\cline { 2 - 6 } & CR & EN & VU & NT & LC & DD \\
\hline CNCFlora & 6 & 17 & 4 & 2 & 3 & 1 \\
MMA & 4 & 16 & 3 & 0 & 0 & 0 \\
Regional RS & 14 & 23 & 7 & 0 & 0 & 3 \\
Regional SC & 2 & 18 & 2 & 1 & 0 & 0 \\
$\begin{array}{l}\text { New assessments } \\
\text { produced here }\end{array}$ & 41 & 26 & 0 & 3 & 3 & 0 \\
\hline
\end{tabular}

Species List from Santa Catarina state (Reis \& Sedrez 2008), and 7.5\% (23 taxa) were included in the List of Rare Plants from Brazil (Giulietti et al. 2009). From the 116 sampled endemic taxa, 24\% (28 taxa) are included in the Red List of Brazilian Flora (Martinelli \& Moraes 2013), 16\% (19 taxa) were included in the national list of threatened species by Ministry of the Environment (Brasil 2014), $20 \%$ (23 taxa) were included in the List of
Threatened Species from Rio Grande do Sul state (Rio Grande do Sul 2015), 6\% (7 taxa) were listed in the Threatened Species List from Santa Catarina state (Reis \& Sedrez 2008), and 4.5\% (5 taxa) were included in the List of Rare Plants from Brazil (Giulietti et al. 2009). However, none of the studied taxa were evaluated and included in the IUCN Red List (IUCN 2015), highlighting the scarcity of data concerning CCS endemic taxa. We assessed the

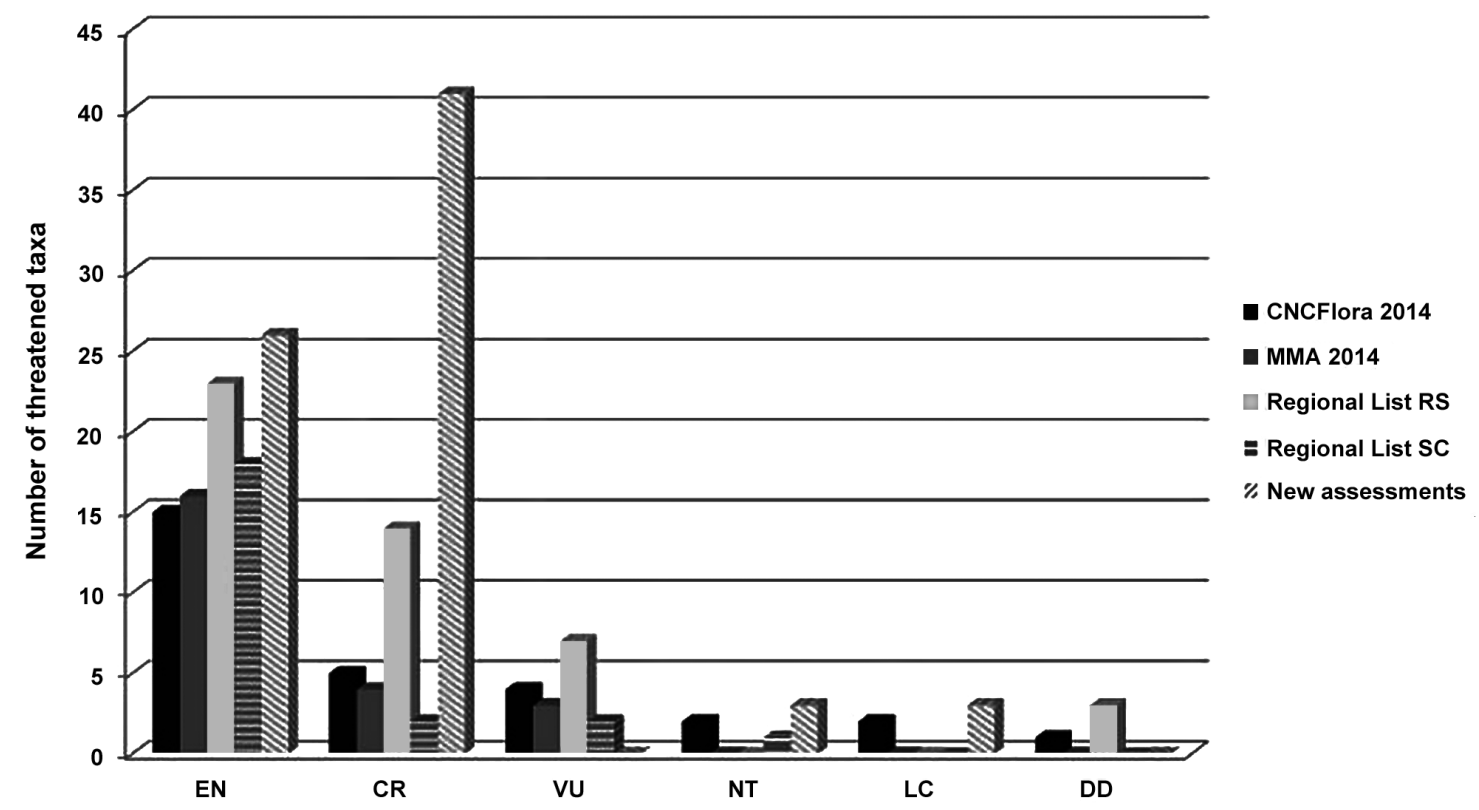

Figure 5 - Number of species per threat category according to the red lists: CNCFlora 2014, MMA 2014, Regional list RS, Regional list SC and new assessments. 
conservation status of 73 endemic taxa for the first time. From these, 41 were categorized as Critically Endangered (CR), 26 as Endangered (EN), three as Near Threatened (NT), and three as Least Concern (LC) (Tab. 1 in supplementary material <https:// figshare.com/s/71d93f859b513760c760>).

\section{Discussion}

Species rich areas usually represent small patches with specific habitat conditions, each one concentrating a unique set of species with restricted distributions (Sankaran 2009). Even though there is a clear concentration of endemic species richness over the northeast of Rio Grande do Sul state, central highlands of Santa Catarina state, and east of Paraná state, the species rich flora over central and west areas of the three states are still poorly known. Besides having high levels of endemic plant taxa, those areas have very scarce records in herbaria collections. Most of the taxa listed as endemic from the CCS are poorly known. There are no records and distribution data for 133 taxa (45\% of total) listed by Iganci et al. (2011) and 47 taxa (16\% of total) presented record outside the CCS. For those taxa there is no conclusive information concerning its geographic distribution, ecological observations, and conservation. The lack of information makes those taxa of high relevance for future studies on Southern Brazilian grasslands conservation. Even with the increase of georeferenced samples in online databases there are few samples for the endemic taxa of CCS, showing the rarity of these taxa and at the same time the low number of collections in this vegetation.

The higher collection richness values within the CCS are found in three main grassland regions: the East of Paraná state near Curitiba, the Eastern edge of Serra Geral in Rio Grande do Sul and Santa Catarina states, and the Central grasslands in the border between Santa Catarina and Paraná (Fig. 3). Besides those areas being species rich areas, this result could also be related to the heterogeneity microhabitats, due to the study involves rupestrian formations, wetlands, peatlands and transition areas such as the fields of Vila Velha Park in Paraná, that form an ecotone with the Cerrado. The higher concentration of research projects in these areas directs of collections efforts in those regions due the concentration of larger protected areas and by the scenic value of the landscapes. The same result is observed in the study of Echternacht et al. (2011) and the authors they cite the influence of collection efforts in results.
On the other hand, the low amount of collections inside protected areas could also be due to the bureaucratic rules to get permits to collect inside those areas. Therefore, there are many collections from areas nearby but not inside the protected areas, decreasing the quality of information about the amount of species protected inside the units. Moreover, low accuracy of GPS devices could also produce false negatives of the records not occurring inside protected areas, but nearby. Sometimes it is possible to check this information using collections information and observations from the herbarium sheet label or online databases produced from it. Thus we analyzed case by case to find out whether a collection was made inside a protected area or nearby but we depended on the information of the researchers who collected, identified and digitized this information. Species circumscription and species concept adopted by different taxonomists could also represent an important rule when establishing threatened species red lists (Knapp et al. 2005; Nick et al. 2004). Taxonomic inflation by elevating infraspecific taxa to the species level could super estimates red lists, at the same time that more comprehensive species circumscriptions could subestimate local variations and the need of conservation of ecological and evolutionary processes (Aleixo 2009). Moreover, many collections made inside conservation areas, as indicated in the herbarium labels, do not have available coordinates due to the lack of GPS equipment to georeference the record. In these cases, databases usually apply the centroid coordinates of the nearest municipality, also producing a false negative about the lack of records from protected areas. Maldonado et al. (2015), working on the tribe Cinchoneae (Rubiaceae), found a similar situation where many of the georeferenced records were based on the municipalities centroids. Those georeferences are attributed after the collections, based on the locations, municipalities or even the states, without detailed information. It is usually possible to identify this situation while cleaning up the dataset. Thus, we highlight that the datasets are passible of many errors when not passing by an exhaustive data cleaning. Mistakes in this magnitude could strongly affect the results producing misinterpretations on species rich areas or false diversity centers. However, when using online databases carefully, after a good data cleaning, a series of advantages are provided, such as being possible to obtain a great amount of data in a short time; and the financial savings in 
comparison with manual data surveys in herbaria (Maldonado et al. 2015).

Considering the taxa with records inside protected areas, a great amount of collections is concentrated in the Eastern edge of the Serra Geral range, in Southern Santa Catarina and Northeast of Rio Grande do Sul states. These locations represent the most diverse areas in endemic plant species within the CCS. Other locations as near the municipality of Curitiba, in Paraná state, show high richness of endemic plants, but few protected areas to protect those taxa. It is probably due to the possibilities that the region lacks large protected areas, the studied taxa were usually collected outside protected areas in the region, and many georeferenced data for collections in this region have only the centroid coordinate of the municipality, with little information about the records location.

It is extremely important that protected areas could be recognized as effective and primordial tools for the maintenance of biological diversity in all different vegetation formations that compound the Southern Brazilian flora. The São Joaquim National Park is the conservation unit with higher number of endemic plants from the CCS. Considering only the taxa selected and mapped in this work, 30\% were recorded from the São Joaquim National Park. The analyses of collection richness and species richness of taxa showed that this protected area has a great relevance as a conservation tool for a great number of endemic taxa from the CCS. Wulff et al. (2013), while studying the distribution and conservation of endemic plants from New Caledonia, suggested that analyses on species distributions can be used to indicate which taxa are susceptible to species loss in front of habitat destruction in a specific location; the same subject is pinpointed by Särkinen et al. (2011).

Therefore, considering the information on the range of distribution, it is possible to develop more effective public policies on conservation, to protect specific endangered narrow endemic taxa (Wulff et al. 2013). A floristic study in Northeast Rio Grande do Sul and Southeast Santa Catarina states, also highlighted those regions as rich in endemic plants and harboring many threatened species (Boldrini et al. 2009). Those results are in accordance with our findings in indicating those areas as priority for conservation. Besides those areas, Barros et al. (2015) also showed the Central regions of Santa Catarina and Paraná states as presenting a great species diversity based on phylogeography approaches and ecological niche modelling. Our results are in agreement with those findings and here we suggest three main diversity areas as conservation priorities and for future studies and public policies: 1) the Eastern edge of the Serra Geral, including a continuous area from the Northeast of Rio Grande do Sul to the Southeast of Santa Catarina states; 2) the Central region of the states of Santa Catarina and Paraná, from Campos de Palmas and Água Doce, in Santa Catarina, up to Palmas and Guarapuava in Paraná; and 3) the Southeast of Paraná state, near Curitiba. A study by Loyola et al. (2014) pointed out some areas as priorities for conservation and sustainable use of the Brazilian threatened flora. Their results are in agreement with our findings when indicating the Northeast of Rio Grande do Sul state, and the South of Santa Catarina state, as well as the municipality of Curitiba and surroundings, in Paraná state, as priority areas for conservation in Southern Brazilian Highlands. However, another region highlighted here by having a great species richness, but low collection richness due the lack of floristic studies was not mentioned by Loyola et al. (2014). This Central region of the states of Santa Catarina and Paraná represent a promising area for future studies on biodiversity since it is one of the species richest areas within the CCS, even though not well studied at all. This might be one of the most important areas for the establishment of new protected areas within the Southern Brazilian highland grasslands. The remaining regions indicated as priority for conservation within the CCS have important protected areas, and the extension of those areas would represent a great step forward for the conservation of the CCS endemics.

A study on the distribution of endemic plants from Peru showed that the occurrence of endemism in higher altitudes $(2,000-3,500 \mathrm{~m})$ is from ten to fifteen times higher than areas with lower altitudes $(0-500 \mathrm{~m})$, and that those plants from higher altitude areas are mainly herbs, shrubs and epiphytes (Werff \& Consiglio 2004). The vegetation over the CCS, the highest formation in Southern Brazil, has a similar pattern since most of the plant species studied here are herbs and shrubs, being the richest formation in endemic plants from Southern Brazil (Iganci et al. 2011). On the other hand, due the land use by agriculture and forestry that have intensified in the last decades on the CCS, it is urgent the establishment of conservation policies which balances economic activities and 
conservation. An effective way of conservation of grasslands in Southern Brazil could be increasing the cattle grazing in controlled conditions as an economic alternative, and a proper management, as it is for the Pampas grasslands (Castilhos et al. 2009; Vélez-Martin et al. 2015; Andrade et al. 2016), besides establishing more Protected Areas.

Many studies suggest that the history of the Southern Brazilian flora has a strong relation with the geological and climate events occurred in the past, contributing for the existence of a highly diverse and exclusive local flora (Smith 1962; Rambo 1953; Safford 2007; Iganci et al. 2013). Veldman et al. (2015) developed the concept of old-growth grasslands, and present a panel with a set of characteristics for lowland to midelevational, tropical and temperate ecosystems. Most of them could also be applied to the highelevation grasslands studied here. The high altitude grasslands from Southern Brazil are in a transition area where we find both tropical and temperate plant lineages (Waechter 2002). Those differences could be observed both on the climate and on the species composition in the region, which provides a differentiated environment and promotes species adaptations and diversification. Thus, the CCS represents an extremely exclusive environment, floristically diverse, and needs to be protected to ensure the maintenance of its natural richness. This vegetation harbors an extremely exclusive biodiversity with a complex history of species diversification (Lorenz-Lemke et al. 2010).

Brazil has a continental territory and it is still necessary to increase the knowledge on the conservation status of its flora. None of the endemic species from the CCS is assessed by the IUCN (2015). Some (41) of the analyzed taxa are listed on national or regional red lists. Being restrict taxa, many of them present high degree of threat (Tab. 1 in supplementary material <https://figshare.com/ s/71d93f859b513760c760>; Tab. 2; Fig. 4; Fig. 5). Besides the few species analyzed for threats, most of them appear as CR and EN in both regional and National red lists. This result indicates the high level of threat faced by those taxa. Considering the restrict distribution as one of the main factors leading to threat within the CCS endemics, most of the other taxa which are also narrow endemic and were not evaluated would probably have similar threat levels. Since the rarest and more restrict species are the most likely to face extinction risks, the exclusive flora from the CCS is extremely threatened. Those species are very specific to a more restrict ensemble of environmental traits, or have low vagility not being able to occupy new areas. The CCS has to be protected before larger biodiversity losses occur. Thus, we reinforce the need of establishing new protected areas to the remaining patches of the highland grasslands from Southern Brazil. Protecting the local diversity including all different grasslands vegetations, from humid to rocky patches, would increase species protection and prevent habitat loss.

\section{Acknowledgements}

The authors would like to thank the Brazilian National Council of Technological and Scientific Development (CNPq-444183/2014-0), for supporting this project.

\section{References}

Aleixo A (2009) Conceitos de espécie e suas implicações para a conservação. Megadiversidade 5: 87-95.

Almeida JA (2009) Fatores Abióticos. In: Boldrini (ed.) Biodiversidade dos Campos do Planalto das Araucárias. MMA, Brasília. Pp. 19-38.

Andrade BO, Bonilha CL, Ferreira PMA, Boldrini II \& Overbeck GE (2016) Highland grasslands at the southern tip of the atlantic forest biome: management options and conservation challenges. Oecologia Australis 20: 37-61. DOI: 10.4257/ oeco.2016.2002.04

Bachman S, Moat J, Hill AW, Torre J \& Scott B (2011) Supporting red list threat assessments whit GeoCAT: geospatial conservation assessment tool. Zookeys 150. Available at <http://geocat.kew.org/what $>$. Access on 3 April 2017.

Barros MJF, Silva-Arias GA, Fregonezi JN, TurchettoZolet AC, Iganci JRV, Diniz-Filho JAF \& Freitas LB (2015) Environmental drivers of diversity in Subtropical Highland Grasslands. Perspectives in Plant Ecology, Evolution and Systematics 7: 360368. DOI: $10.1016 /$ j.ppees.2015.08.001

Behling H (2002) South and southeast Brazilian grasslands during Late Quaternary times. A synthesis. Palaeogeography, Palaeoclimatology, Palaeoecology 177: 19-27.

Behling H \& Pillar VP (2007) Quaternary vegetation, biodiversity and fire dynamics on the southern Brazilian highland and their implication for conservation and management of modern Araucaria forest and grassland ecosystems. Philosophical Transactions of the Royal Society B 362: 243-251.

BFG - The Brazil Flora Group (2015) Growing knowledge: an overview of seed plant diversity in Brazil. Rodriguésia 66: 1085-1113.

Boldrini I, Eggers L, Mentz LA, Miotto STS, Matzenbacher NI, Longhi-Wagner HM, Trevisan 
R, Schneider AA \& Setúbal RB (2009) Flora. In: Boldrini I (ed.) Biodiversidade dos Campos do Planalto das Araucárias. 2 ${ }^{\text {a }}$ ed. MMA, Brasília. Pp. 39-94.

Brasil (2008) Ministério do Meio Ambiente. Secretaria de Biodiversidade e Florestas - SBF/MMA. Available at $<$ http://www.mma.gov.br/port/conama/ processos/3AA1D219/ParecerMMA Campos Altitude_70209.pdf $>$. Access on 20 October 2013.

Brasil (2012) IBGE - Instituto Brasileiro de Geografia e Estatística. Manual técnico da vegetação brasileira. Rio de Janeiro. Available at $<$ ftp://geoftp.ibge. gov.br/documentos/recursos naturais/ manuais tecnicos/manual tecnico ve getacao brasileira. pdf $>$. Access on 3 May 2014.

Brasil (2014) Instituto Chico Mendes. Available at $<$ http://www.icmbio.gov.br/portal $>$. Access on 3 May 2014.

Brazilian Flora (2020 in construction) Rio de Janeiro Botanical Garden. Available at: $<$ http://floradobrasil. jbrj.gov.br/>. Access on: 23 August 2016.

Castilhos ZMS, Machado MD \& Pinto MF (2009) Produção animal com conservação da flora campestre do bioma Pampa. In: Pillar VP, Müller SC, Castilhos ZMS \& Aino VAJ (ed.) Campos Sulinos: conservação e uso sustentável da biodiversidade. $2^{\mathrm{a}}$ ed. MMA, Brasília. Pp. 199-205.

Duarte LS, Dos-Santos MMG, Hartz SM \& Pillar VP (2006) Role of nurse plants in Araucaria Forest expansion over grassland in south Brazil. Austral Ecology 31: 520-528.

Dixon AP, Faber-Langendoen D, Josse C, Morrison J \& Loucks CJ (2014) Distribution mapping of world grassland types. Journal of Biogeography 41: 2003 2019. DOI: $10.1111 /$ jbi.12381

Fortes AB (1959) Geografia física do Rio Grande do Sul. Ed. Globo, Porto Alegre. 393p.

Giulietti AM, Rapini A, Andrade MJG, Queiroz LP \& Silva JMC (2009) Plantas raras do Brasil. Conservação Internacional, Belo Horizonte. Pp. 23-35.

Iganci JRV, Heiden G, Miotto STS \& Pennington RT (2011) Campos de Cima da Serra: the Brazilian Subtropical Highland Grasslands show an unexpected level of plant endemism. Botanical Journal of the Linnean Society 167: 378-393.

Iganci JRV, Miotto STS, Chies T, Sarkinen T, Simpson B, Simon MF \& Pennington RT (2013) Diversification history of Adesmia ser. psoraleoides (Leguminosae): evolutionary processes and the colonization of the southern Brazilian highland grasslands. South African journal of Botany 89: 257-264.

IUCN (2015) The IUCN red list of threatened species. Available at $<\mathrm{http}: / / \mathrm{http}: / /$ www.iucnredlist.org $>$. Access on 3 July 2015.

Knapp S, Eimear NL \& Alan P (2005) Taxonomic inflation, species concepts and global species lists. Trends in Ecology and Evolution 20: 7-8.
Köppen W (1931) Grundriss der Klimakunde. Walter de Gruyter, Berlin. 390p.

Lorenz-Lemke AP, Togni PD, Mäder G, Kriedt RA, Stehmann JR, Salzano FM, Bonatto SL \& Freitas LB (2010) Diversification of plant species in a subtropical region of eastern South American highlands: a phylogeographic perspective on native Petunia (Solanaceae). Molecular Ecology 19: 5240-5251.

Loyola R, Machado N, Nova DN, Martins E \& Martinelli G (2014) Áreas prioritárias para conservação e uso sustentável da flora brasileira ameaçada de extinção. CNCFlora, Rio de Janeiro. 80p.

Lopes F, Mielniczuk J, Oliveira ES \& Tornquist CG (2010) Evolução do uso do solo em uma área piloto da região de Vacaria, RS. Revista Brasileira de Engenharia Agrícola e Ambiental 14: 1038-1044.

Maldonado C, Molina CI, Zizka A, Persson C, Taylor CM, Albán J, Chilquillo E, Ronsted N \& Antonelli A (2015) Estimating species diversity and distribution in the era of big data: to what extent can we trust public databases? Global Ecology and Biogeography 24: 973-984.

Martinelli G \& Moraes MA (2013) Livro vermelho da flora do Brasil. CNCFlora, Rio de Janeiro. 1100p.

Nick JB, James M \& Georgina MM (2004) Taxonomic inflation: its influence on macroecology and conservation. Trends in Ecology and Evolution 19: 464-469.

Overbeck GE, Muller SC, Fidelis A, Pfadenhauer J, Pillar VD, Blanco CC, Boldrini II, Both R \& Forneck ED (2007) Brazil's neglected biome: the South Brazilian Campos. Perspectives in Plant Ecology, Evolution and Systematics 9: 101-116.

Overbeck GE, Velez-Martin E, Scarano FR, Lewinsohn TM, Fonseca CR, Meyer ST, Muller SC, Ceotto P, Dadalt L. Durigan G, Ganade G, Gossner MM, Guadagnin DL, Lorenzen K, Jacobi CM, Weisser WW \& Pillar VD (2015) Conservation in Brazil needs to include non-forest ecosystems. Diversity and Distributions 21: 1455-1460. DOI: 10.1111/ ddi. 12380

Rambo B (1953) História da flora do planalto riograndense. Anais Botânicos do Herbário Barbosa Rodrigues 5: 185-232.

Reis A \& Sedrez MR (2008) II Workshop sobre a lista das espécies da flora catarinense ameaçadas de extinção, Florianópolis. 101p.

Rio Grande do Sul (2015) Espécies ameaçadas de extinção da flora do Rio Grande do Sul. Available at $<$ http://www.biodiversitas.org.br/florabr/rs-especiesameacadas.pdf $>$. Access on 14 March 2015.

Rösch V, Tscharntke T, Scherber C \& Batáry P (2015) Biodiversity conservation across taxa and landscapes requires many small as well as single large habitat fragments. Oecologia 179: 209-222.

Sankaran M (2009) Diversity patterns in savanna grassland communities: implications for conservation 
strategies in a biodiversity hotspot. Biodiversity Conservation 18: 1099-1115. DOI: 10.1007/s10531008-9519-9

Safford HD (2007) Brazilian páramos IV. Phytogeography of the campos de altitude. Journal of Biogeography 34: 1701-1722.

Särkinen T, Iganci JRV, Linares-Palomino R, Simon MF \& Prado DE (2011) Forgotten forests - issues and prospects in biome mapping using Seasonally Dry Tropical Forests as a case study. BioMed Central Ecology 11: 27. DOI: 10.1186/1472-6785-11-27

Scheibe LF (1986) A geologia de Santa Catarina. Florianópolis. Geosul, n. 1. Pp. 7-38.

Smith LB (1962) Origins of the flora of southern Brazil. Contributions from the United States National Herbarium 35: 215-249.

Vélez-Martin E, Fante E, Dotta G, Silva TW, Fontana CS \& Pillar VP (2015) Cidadania e uso sustentável dos campos. In: Pillar VP \& Lange O (eds.) Os campos do Sul. UFRGS, Porto Alegre. Pp. 155-166.
Vieira LTA, Polisel RT, Ivanauskas NM, Shepherd GJ, Waechter JL, Yamamoto K \& Martins FR (2015) Geographical patterns of terrestrial herbs: a new component in planning the conservation of the Brazilian Atlantic Forest. Biodiversity and Conservation 24: 2181-2190. DOI: $10.1007 /$ s10531015-0967-8

Waechter JL (2002) Padrões geográficos na flora atual do Rio Grande do Sul. Ciência and Ambiente 24: 93-108.

Werff HVD \& Consiglio T (2004) Distribution and conservation significance of endemic species of flowering plants in Peru. Biodiversity and conservation 13: 1699-1713.

Wulff AS, Hollingsworth PM, Ahrends A, Jaffre T, Veillon JM, Huillier LL \& Fogliani B (2013) Conservation priorities in a biodiversity hotspot: analysis of narrow endemic plant species in New Caledonia. PLOS ONE. 14p. DOI: 10.1371/journal. pone. 0073371 